\title{
Isolation and characterization of bacteriophages against virulent Aeromonas hydrophila
}

\author{
Jin Liu', Shanshan Gao², Yuhao Dong ${ }^{1}$, Chengping Lu and Yongjie Liu ${ }^{1 *}$
}

\begin{abstract}
Background: Aeromonas hydrophila is an important water-borne pathogen that leads to a great economic loss in aquaculture. Along with the abuse of antibiotics, drug-resistant strains rise rapidly. In addition, the biofilms formed by this bacterium limited the antibacterial effect of antibiotics. Bacteriophages have been attracting increasing attention as a potential alternative to antibiotics against bacterial infections.

Results: Five phages against pathogenic A. hydrophila, named N21, W3, G65, Y71 and Y81, were isolated. Morphological analysis by transmission electron microscopy revealed that phages N21, W3 and G65 belong to the family Myoviridae, while Y71 and Y81 belong to the Podoviridae. These phages were found to have broad host spectra, short latent periods and normal burst sizes. They were sensitive to high temperature but had a wide adaptability to the $\mathrm{pH}$. In addition, the phages G65 and Y81 showed considerable bacterial killing effect and potential in preventing formation of $A$. hydrophila biofilm; and the phages G65, W3 and N21 were able to scavenge mature biofilm effectively. Phage treatments applied to the pathogenic A. hydrophila in mice model resulted in a significantly decreased bacterial loads in tissues.
\end{abstract}

Conclusions: Five A. hydrophila phages were isolated with broad host ranges, low latent periods, and wide $\mathrm{pH}$ and thermal tolerance. And the phages exhibited varying abilities in controlling A. hydrophila infection. This work presents promising data supporting the future use of phage therapy.

Keywords: Aeromonas hydrophila, Bacteriophage, Biological characteristics, Biofilm, Phage therapy

\section{Background}

Aeromonas hydrophila is a Gram-negative, rod-shaped bacterium that is ubiquitous found in natural aquatic environments. The bacterium is predominantly pathogenic to poikilothermy animals, including fish, turtles, snakes and amphibians [1]. It is responsible for the large-scale outbreak of fish hemorrhagic septicemia, leading to severe economic losses to aquaculture industry worldwide [2]. The bacterium is also an important pathogen that infects humans and other mammals, causing gastroenteritis and

\footnotetext{
* Correspondence: liuyongjie@njau.edu.cn

'Joint International Research Laboratory of Animal Health and Food Safety,

College of Veterinary Medicine, Nanjing Agricultural University, Nanjing 210095, China

Full list of author information is available at the end of the article
}

various systemic infections. A.hydrophila is a very typical pathogen of human-animal-fish comorbidity [1].

In general, the prevention and treatment of diseases depend mainly on extensive application of antimicrobial agents $[3,4]$. Antibiotics not only kill the target bacteria, but might also disrupt the host's normal flora and the ecological balance of the water environment [5]. With the frequent use of antibacterial drugs in aquaculture, multidrug resistance (MDR) of $A$. hydrophila strains are emerging; and drug residues in aquaculture products and the environment are getting worse [6-8]. Vivekanandhan et al. [9] indicated that $99 \%$ of $A$. hydrophila strains isolated from fish and prawns were resistant to methicillin, rifampicin, bacitracin, and novobiocin. Recently, De Silva et al. [10] tested antibiotic resistance of 32 strains of Aeromonas,

(c) The Author(s). 2020 Open Access This article is licensed under a Creative Commons Attribution 4.0 International License, which permits use, sharing, adaptation, distribution and reproduction in any medium or format, as long as you give appropriate credit to the original author(s) and the source, provide a link to the Creative Commons licence, and indicate if changes were made. The images or other third party material in this article are included in the article's Creative Commons licence, unless indicated otherwise in a credit line to the material. If material is not included in the article's Creative Commons licence and your intended use is not permitted by statutory regulation or exceeds the permitted use, you will need to obtain permission directly from the copyright holder. To view a copy of this licence, visit http://creativecommons.org/licenses/by/4.0/ The Creative Commons Public Domain Dedication waiver (http://creativecommons.org/publicdomain/zero/1.0/) applies to the data made available in this article, unless otherwise stated in a credit line to the data. 
and found that all the isolates were multidrug resistant and $100 \%$ resistant to ampicillin, colistin, vancomycin and cephalothin. In addition, each of the 43 Aeromonas strains isolated by Hossain et al. [11] from 46 zebrafish was resistant to at least four antibiotics. MDR strains can reproduce and pass its resistance on, creating many more antibiotic resistant bacteria $[12,13]$. Additionally, many bacterial infections are due to biofilm-embedded bacteria [14]. A. hydrophila is capable of forming biofilms on host tissues, as well as multiple biotic and abiotic aquaculture substrates [15]. Bacteria within a biofilm are more resistant to antibiotics compared to those in the planktonic style, since biofilm structure provides a reduced penetration of antibacterial compounds into the biofilm [16, 17], which make treatment of bacterial infections face a serious challenge. Thus, new antimicrobial therapies are urgent to be developed.

Bacteriophages, naturally-occurring bacterial viruses that can kill specific bacteria with no chemical residues and does not affect other flora, are one of the potential alternatives. A small dose of phage can achieve a good therapeutic effect as phage proliferation via auto "dosing" results in great bacterial killing [18]. One previous study from Nishikawa et al. [19] reported that phage KEP10 intraperitoneally injected into mice could immediately spread to all organs examined and maintained a high titer; and treatment of the phage into the peritoneal cavity significantly decreased the mortality of mice inoculated transurethrally with a multidrug-resistant strain of uropathogenic Escherichia coli (UPEC). Another study indicated that infection of methicillin-resistant Staphylococcus aureus with subsequent administration of purified phage phi MR11 effectively suppressed $S$. aureus-induced bacteremia and lethality in mice [20]. Phage therapy has also shown its efficacy in several cases of Aeromonas diseases. Jun et al. [21] reported that phages pAh1-C and pAh6-C could provide protective effects against mass mortality of the cyprinid loach caused by A. hydrophila. Additionally, therapeutic treatments of A. hydrophilaphage 2 and $A$. hydrophila-phage 5 applied to the catfish during bacterial infection resulted in a significantly enhanced survival of the tested fishes [22]. However, not all phages make for good therapeutics. In general, the narrowness of phage host ranges will limit putative treatment and the lack of phage stability will reduce treatment efficiency. Thus, it is necessary to isolate stable phages with relatively wide host ranges for phage therapy.

In this study, we isolated and characterized five phages specific to $A$. hydrophila. Furthermore, we investigated the efficiency of the phages for biofilm inhibition and removal, and performed a phage therapy experiment in $A$. hydrophila-infected mice.

\section{Results}

\section{Isolation of $A$. hydrophila phages}

Three phages designated as N21, W3 and G65 with $A$. hydrophila NJ-35 as an indicator host, and two phages Y71 and Y81 with A. hydrophila XY-16 as an indicator host, were isolated from fish ponds and polluted rivers in Nanjing. Clear plaques appeared after $12 \mathrm{~h}$ incubation at $28^{\circ} \mathrm{C}$. As shown in Fig. 1a, plaques of all the five phages were morphologically similar with diameters of 1 $\mathrm{mm}$ to $3 \mathrm{~mm}$, and transparent in the middle. The plaque edges of phages W3, Y71 and Y81 were clear with no halo, while those of phages N21 and G65 were blurred with haloes.

\section{Phage morphology}

Purified phages were examined by transmission electron microscopy (TEM) and classifed based on the criteria proposed by Ackermann [23]. TEM observation revealed that all the phages (Fig. 1b) had tails and thus belonged to the order Caudovirales. Phages N21, W3 and G65 possessed a morphology typical of the Myoviridae family, displaying an icosahedral head with the diameter of $(62.6 \pm 1.9) \mathrm{nm},(64.9 \pm 3.2) \mathrm{nm}$ and $(58.8 \pm 4.1) \mathrm{nm}$, respectively, a contractile tail with the length of (153.1 \pm 6.2) $\mathrm{nm},(154.1 \pm 1.4) \mathrm{nm}$ and $(152.3 \pm 9.8) \mathrm{nm}$ with six long fibers, respectively, and collar and base plate structures. Phages Y71 and Y81 morphologically belonged to the Podoviridae family, possessing an icosahedral head of $(62.8 \pm 1.1) \mathrm{nm}$ and $(54.8 \pm 2.9) \mathrm{nm}$ in diameter, respectively, and a short tail of $(22.0 \pm 0.2) \mathrm{nm},(20.0 \pm 2.2)$ $\mathrm{nm}$ in length, respectively.

\section{Host ranges}

The lytic spectrum of five phages was determined against nine Aeromonas species of a total of 205 isolates, including $75 \mathrm{~A}$. hydrophila, $85 \mathrm{~A}$. veronii, $12 \mathrm{~A}$. caviae, 1 A. bestiarum, 12 A. sobria, 10 A. media, 3 A. salmonicida, $3 A$. jandaei and $4 A$. aquariorum (Table 1), representative of major Aeromonas species pathogenic in fish. As shown in Table 2, it was found that 22.67\% $(n=17)$, $21.33 \%(n=16), 21.33 \%(n=16), 20 \%(n=15)$ and $22.67 \%$ $(n=17)$ of $75 \mathrm{~A}$. hydrophila isolates were susceptible to phages N21, W3, G65, Y71 and Y81. Additionally, all of the phages could infect one strain of $A$. caviae; phages N21, W3 and G65 also showed infectivity to $A$. veronii of 1,3 , and 3 strains, respectively; and phage W3 was able to infect the only $A$. bestiarum isolate tested in this study, showing broad infectivity against phylogenetically distant species in Aeromonadaceae.

\section{Multiplicity of infection (MOI)}

A. hydrophila cultures of exponential growth phase were infected with different amount of phages as designed. The phage titers were measured after incubation for $2 \mathrm{~h}$. 


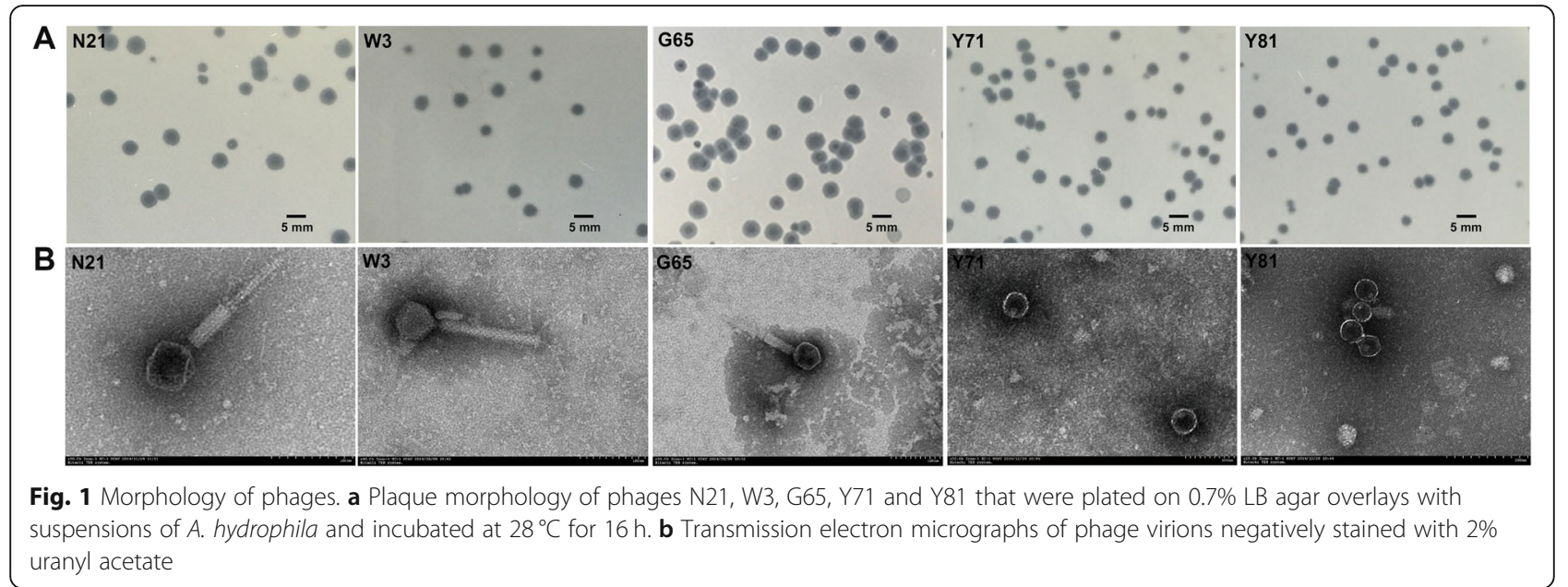

The results indicated that the optimal MOIs of phage isolates N21, W3, G65, Y71 and Y81 were 0.01, 1, 0.001, 0.1 and 0.001 , respectively, which gave the highest production of phage progeny (Table 3).

\section{Latent times and phage burst sizes}

Single step growth experiment was performed to determine the latent time and phage burst size. As shown in Fig. 2, the latent periods of all five phages were found to be about $15 \mathrm{~min}$, and the burst sizes of phages N21, W3,
G65, Y71 and Y81 were 316 PFU, 160 PFU, 210 PFU, 200 PFU and 220 PFU per infected host cell, respectively.

\section{$\mathrm{pH}$ and thermal stability}

The $\mathrm{pH}$ and thermal stabilities of phages were estimated by determining the changes in survival based on the number of plaque-forming units (PFU). As shown in Fig. 3, growth of phage N21 showed no obvious change after $2 \mathrm{~h}$ incubation at $\mathrm{pH} 5.0-11.0$, but $75.26 \%$ recovery at $\mathrm{pH}$ 4.0. The survival of phage W3 could maintain

Table 1 Aeromonas strains used in this study

\begin{tabular}{|c|c|c|c|c|}
\hline \multirow{2}{*}{$\begin{array}{l}\text { Aeromonas } \\
\text { species }\end{array}$} & \multicolumn{4}{|l|}{ Sources } \\
\hline & Fish & Shrimp & Crab & Water \\
\hline A. hydrophila & $\begin{array}{l}\text { NJ-35, XY-16, XX-58, NJ-34, NJ-28, ML-2, ML-11, ML-15, XH- } \\
\text { 3, XS-1, XS-6, XS-7, XH-3 NJ-1, XX-11, XX-12, XX-13, XX-14, } \\
\text { NJ-28, JH-19, CS-60, J-1, DW-4, ML-9, ML-13, ML-21, XH-5, } \\
\text { CH-2, XS-5, XS-10, CH-8, XS-12, XH-5 XX-49, XX-52, JH-17, } \\
\text { DW-2, ML-4, ML-16, ML-22, CH-1, CH-6, XS-3, XS-9, XS-11, } \\
\text { JD-3, GY-23, DW-3, ML-12, ML-19, ML-23, XH-1, XH-6, CH- } \\
\text { 3, CH-10, XS-4, JD-4, XH-1, XH-6, XX-62, DW-1, ML-5, ML- } \\
\text { 14, ML-17, ML-26, CH-4, CH-11, CH-9, XS-2, JD-1, JD-2 }\end{array}$ & & & ML-30, ZG-22, SQ-11, NJ-3 \\
\hline A. veronii & $\begin{array}{l}\text { XH-4, XH-5, CH-5, DS-4, DS-6, ML-10, LK-1, ZG-15, ZG-5, } \\
\text { ZG-2, GY-37, GY-28, GY-13, ML-10 LK-1, ML-25, CH-7, CH- } \\
\text { 12, DS-1, ML-3, ZG-12, ZG-11, ZG-10, ZG-6, ZG-4, GY-41, } \\
\text { GY-40, DS-7, ML-3, ML-25, GY-36, DS-2, DS-5, ML-24, ZG- } \\
\text { 17, ZG-13, DS-9, XH-4, ML-24, DS-3, ML-6, ZG-18, ZG-14, } \\
\text { GY-36, DS-8, DS-10, LK-16, LK-15, ML-6, LK-3, SQ-4, SQ-2, } \\
\text { ZG-16, ZG-9, ZG-7, ZG-3, LK-3 }\end{array}$ & $\begin{array}{l}\text { SQ-5, SQ-6, SQ-7, ML- } \\
8, \text { WX-1, WX-2, WX-3, } \\
\text { WX-4, LK-17 }\end{array}$ & $\begin{array}{l}\text { LK-19, } \\
\text { LK-21, } \\
\text { LK-22 }\end{array}$ & $\begin{array}{l}\text { GY-11, GY-32, GY-53, GY-54, GY-58, ZG-19, } \\
\text { ZG-21, ZG-23, SQ-8, SQ-9, ZX-4, ML-29, } \\
\text { LK-26, XS-13, LK-27, DS-11 }\end{array}$ \\
\hline A. caviae & ML-1, SQ-1, SQ-3, LK-6, LK-10, LK-4, LK-5, XS-8 & ZX-2, LK-18 & LK-20 & $M L-27$ \\
\hline A. bestiarum & & & & NJ-24 \\
\hline A. sobria & LK-2, LK-12, CS-40, GY-45, JH-1, ZG-8, GY-4, LK-14 & $Z X-1$ & & LK-24, ZG-20, SQ-10 \\
\hline A. media & NJ-4, NJ-30, NJ-5, NJ-6, NJ-32 & & & NJ-7, NJ-8, NJ-21, NJ-25, NJ-29 \\
\hline $\begin{array}{l}\text { A. } \\
\text { salmonicida }\end{array}$ & & & & $X X-27, x X-28, C S-2$ \\
\hline A. jandaei & $\mathrm{XH}-2, \mathrm{ZG}-1$ & & & LK-23 \\
\hline A. aquariorum & ML-18, LK-25, ML-20 & & & ML-28 \\
\hline
\end{tabular}


Table 2 The information of the phages isolated in this study

\begin{tabular}{|c|c|c|c|c|c|c|}
\hline \multirow[t]{2}{*}{ Phages } & \multirow[t]{2}{*}{ Sources } & \multirow{2}{*}{$\begin{array}{l}\text { Indicator } \\
\text { bacteria }\end{array}$} & \multicolumn{4}{|l|}{ Host ranges } \\
\hline & & & A. hydrophila & A.caviae & A. veronii & $\begin{array}{l}\text { A. } \\
\text { bestiarum }\end{array}$ \\
\hline $\mathrm{N} 21$ & $\begin{array}{l}\text { Pond water polluted by } \\
\text { diseased fish }\end{array}$ & $\begin{array}{l}\text { A. } \\
\text { hydrophila } \\
\text { NJ-35 }\end{array}$ & $\begin{array}{l}\text { NJ-35, XY-16, J-1, GY-23, NJ-34, XH-3, XH-4, XH-5, XH-6, CH-3, ML-4, } \\
\text { ML-5, ML-11, ML-12, ML-23, CH-8, SQ-11 }\end{array}$ & $M L-27$ & $\mathrm{CH}-7$ & \\
\hline W3 & $\begin{array}{l}\text { Pond water polluted by } \\
\text { diseased fish }\end{array}$ & $\begin{array}{l}\text { A. } \\
\text { hydrophila } \\
\text { NJ-35 }\end{array}$ & $\begin{array}{l}\text { NJ-35, XY-16, GY-23, NJ-34, XH-3, XH-4, XH-5, XH-6, CH-3, ML-4, ML- } \\
\text { 5, ML-11, ML-12, ML-23, CH-8, SQ-11 }\end{array}$ & $M L-27$ & $\begin{array}{l}\text { GY-40, } \\
\text { SQ-7, CH- } \\
7\end{array}$ & NJ-24 \\
\hline G65 & Polluted river & $\begin{array}{l}\text { A. } \\
\text { hydrophila } \\
\text { NJ-35 }\end{array}$ & $\begin{array}{l}\text { NJ-35, XY-16, GY-23, NJ-34, XH-3, XH-4, XH-5, XH-6, CH-3, ML-4, ML- } \\
\text { 5, ML-11, ML-12, ML-23, CH-8, SQ-11 }\end{array}$ & $M L-27$ & $\begin{array}{l}\text { GY-40, } \\
\text { SQ-7, CH- } \\
7\end{array}$ & \\
\hline Y71 & $\begin{array}{l}\text { Pond water polluted by } \\
\text { diseased fish }\end{array}$ & $\begin{array}{l}\text { A. } \\
\text { hydrophila } \\
\text { XY-16 }\end{array}$ & $\begin{array}{l}\text { NJ-35, XY-16, J-1, GY-23, NJ-34, XH-3, XH-4, XH-5, XH-6, ML-4, ML-5, } \\
\text { ML-12, ML-23, CH-3, SQ-11 }\end{array}$ & & $\mathrm{CH}-7$ & \\
\hline Y81 & $\begin{array}{l}\text { Pond water polluted by } \\
\text { diseased fish }\end{array}$ & $\begin{array}{l}\text { A. } \\
\text { hydrophila } \\
\text { XY-16 }\end{array}$ & $\begin{array}{l}\text { NJ-35, XY-16, J-1, GY-23, NJ-34, XH-3, XH-4, XH-5, XH-6, CH-3, ML-4, } \\
\text { ML-5, ML-11, ML-12, ML-23, CH-8, SQ-11 }\end{array}$ & & $\mathrm{CH}-7$ & \\
\hline
\end{tabular}

relatively stable at $\mathrm{pH} 4.0-10.0$; very few phages could recovery at $\mathrm{pH} 3.0$ or $\mathrm{pH}$ 11.0. Phage Y81 displayed similar $\mathrm{pH}$ stability to phage W3. More than $75 \%$ phage G65 could survive at $\mathrm{pH} 4.0-11.0$. Phage Y71 showed relatively stable between $\mathrm{pH} 5.0-10.0$. The data suggested that the phages can remain active under a wide range of $\mathrm{pH}$ conditions but sensitive to strong acid or alkali.

Thermal stability of the isolated phages was assayed at $\mathrm{pH}$ 7.0. All of the five phages maintained almost $100 \%$ infectivity after cultured at $4{ }^{\circ} \mathrm{C}$ or $30^{\circ} \mathrm{C}$ for 1 day (data not shown). Figure 4 showed that all the phages remained relatively stable at $30^{\circ} \mathrm{C}$ and $40^{\circ} \mathrm{C}$, but sensitive to higher temperatures. No more than $50 \%$ phages remained alive after a 40 -min incubation at $50{ }^{\circ} \mathrm{C}$. At $60^{\circ} \mathrm{C}$, no more than $1 \%$ of phages W3, G65, and Y81 survived for $20 \mathrm{~min}$, and phages N21 and Y71 for $40 \mathrm{~min}$.

\section{Bacteriolytic activity in vitro}

The bacteriolytic activities of five phages were evaluated using A. hydrophila strains NJ-35 and XY-16 at different doses of MOIs. As shown in Fig. 5, the absorbance of NJ-35 and XY-16 cultured without phages increased continuously within $24 \mathrm{~h}$, whereas the absorbance of the cultures with the phages increased gradually during the first $2 \mathrm{~h}$, then decreased remarkably in a MOI-dependent manner $(2-6 \mathrm{~h})$, and at $6 \mathrm{~h}$, dropped to the minimum at all different MOIs. From $6 \mathrm{~h}$ to $24 \mathrm{~h}$, the absorbance of the cultures with phage G65 or Y81 remained stable at its lowest level. However, notably, the absorbance of the cultures began to rise remarkably from $12 \mathrm{~h}$ after treatment by phage N21, W3, or Y71.

\section{Effect of phages on bacterial biofilm formation}

The capability of the phages to prevent biofilm formation of A. hydrophila NJ-35 and XY-16 was detected at $24 \mathrm{~h}$ after coculture using crystal violet method. As shown in Fig. 6, compared to A. hydrophila cultured alone, the bacteria cocultured with phages showed a considerably decreased biofilm formation at each MOI, and the decrease was MOI-dependent. At a MOI of 1.0, all the phages exhibited a significantly inhibited effect on the biofilm formation of their corresponding host strains $(P<0.05$ or $P<0.001)$. Interestingly, similar to what was observed in bacteriolytic activity, phages G65 and Y81

Table 3 The optimal $\mathrm{MOI}$ of phage N21, W3, G65, Y71 and Y81

\begin{tabular}{|c|c|c|c|c|c|c|c|}
\hline \multirow{2}{*}{$\begin{array}{l}\text { Bacteria } \\
\text { (CFU/mL) }\end{array}$} & \multirow{2}{*}{$\begin{array}{l}\text { Phages } \\
\text { (PFU/mL) }\end{array}$} & \multirow[t]{2}{*}{$\mathrm{MOI}$} & \multicolumn{5}{|c|}{ Titers of phages after $2 \mathrm{~h}$ co-culture (PFU/mL) } \\
\hline & & & $\mathrm{N} 21$ & W3 & G65 & Y71 & Y81 \\
\hline $10^{6}$ & $10^{8}$ & 100 & $1.28 \times 10^{8}$ & $2.00 \times 10^{8}$ & $1.72 \times 10^{7}$ & $4.00 \times 10^{7}$ & $7.30 \times 10^{7}$ \\
\hline $10^{7}$ & $10^{8}$ & 10 & $2.50 \times 10^{8}$ & $2.50 \times 10^{8}$ & $5.50 \times 10^{7}$ & $2.54 \times 10^{8}$ & $3.55 \times 10^{8}$ \\
\hline $10^{8}$ & $10^{8}$ & 1 & $3.10 \times 10^{8}$ & $6.03 \times 10^{8}$ & $5.70 \times 10^{7}$ & $2.03 \times 10^{9}$ & $3.58 \times 10^{8}$ \\
\hline $10^{8}$ & $10^{7}$ & 0.1 & $4.10 \times 10^{8}$ & $8.00 \times 10^{8}$ & $1.17 \times 10^{8}$ & $2.50 \times 10^{9}$ & $3.60 \times 10^{8}$ \\
\hline $10^{8}$ & $10^{6}$ & 0.01 & $8.93 \times 10^{8}$ & $1.00 \times 10^{8}$ & $2.16 \times 10^{8}$ & $1.15 \times 10^{9}$ & $3.80 \times 10^{8}$ \\
\hline $10^{8}$ & $10^{5}$ & 0.001 & $2.06 \times 10^{8}$ & $1.00 \times 10^{8}$ & $2.31 \times 10^{8}$ & $1.00 \times 10^{9}$ & $4.46 \times 10^{8}$ \\
\hline $10^{8}$ & $10^{4}$ & 0.0001 & $2.0 \times 10^{8}$ & $8.00 \times 10^{7}$ & $2.00 \times 10^{8}$ & $8.60 \times 10^{8}$ & $3.76 \times 10^{8}$ \\
\hline
\end{tabular}




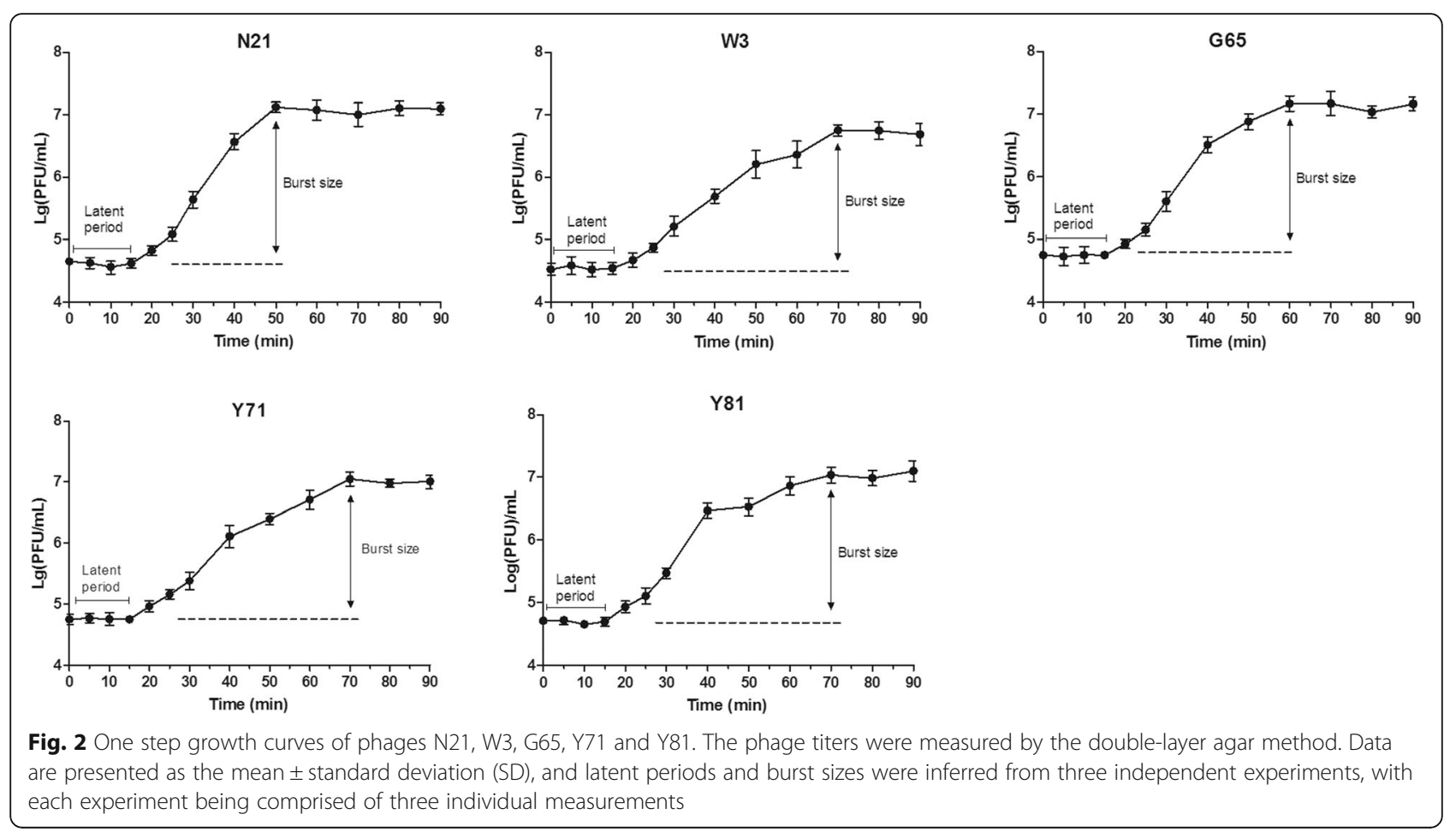

had stronger abilities to prevent biofilm formation than the other three phages. Very few biofilm could be detected when the $A$. hydrophila was incubated with G65 or Y81 even at a small MOI of 0.01 .

\section{Biofilm clearance ability}

Decrease of mature biofilm formed by $A$. hydrophila strain NJ-35 or XY-16 treated with phages with a titer of $1.0 \times 10^{8} \mathrm{PFU} / \mathrm{mL}$ was determined. As shown in Fig. 7, phage treatment caused an obvious reduction in biofilm biomass of $A$. hydrophila in a time-dependent manner, as compared with untreated controls, except for the treatment with phage Y71 which resulted in a slight decrease with no statistical difference. Phages G65, W3

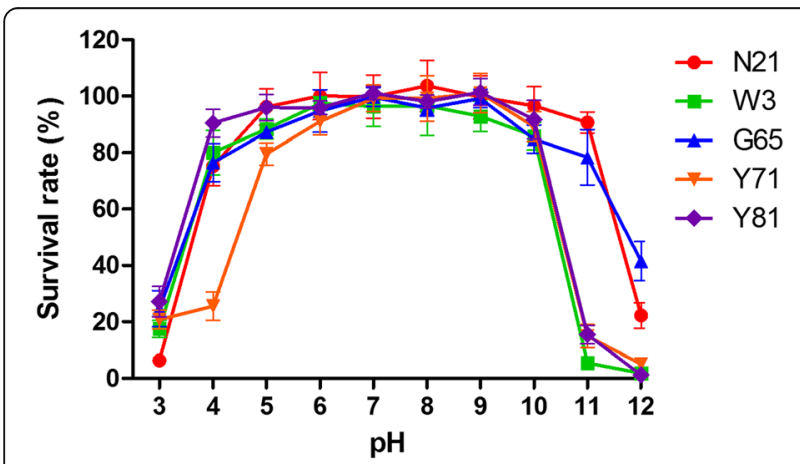

Fig. 3 pH stability of phages N21, W3, G65, Y71 and Y81. Phages were incubated for $2 \mathrm{~h}$ under different $\mathrm{pH}$ values, and the survival rate of phages were shown as mean \pm SD from the triplicate experiments and N21 showed a relatively stronger biofilm clearance efficiency after treating for $24 \mathrm{~h}$, with the clearance rates of $75.12,73.35$ and $67.08 \%$, respectively, whereas phages Y81 and Y71 only exhibited biofilm removal of 34.26 and $12.47 \%$, respectively.

\section{Phage therapy}

To corroborate whether the phages can prevent the proliferation of $A$. hydrophila in vivo, we performed an infection and therapy assay in mice. Mice infected with $A$. hydrophila were sacrificed at $6 \mathrm{~h}$ and $24 \mathrm{~h}$ posttreatment with phages, and hearts, livers, spleens, lungs and kidneys were collected for determination of bacterial loads. As shown in Fig. 8, phages N21 and Y81 treatment lead to significant decrease of the bacterial loads in all tested tissues at $6 \mathrm{~h}$ compared to the non-treated controls. After treating for $24 \mathrm{~h}$, the bacterial loads in all tissues of phage-treated groups showed significant decrease compared to the non-treated controls. The results indicated that the phages can act as scavengers to eliminate pathogens in vivo.

\section{Discussion}

Phage taxonomy has progressed from a mainly morphology-based techniques to the modern applications of a holistic approach [24]. Recently, two new phage families Ackermannviridae and Herelleviridae were established in the order Caudovirales based on virion morphology and genome or proteome comparisons [25, 26]. Nevertheless, the tranditional virion structure observation is still the most 


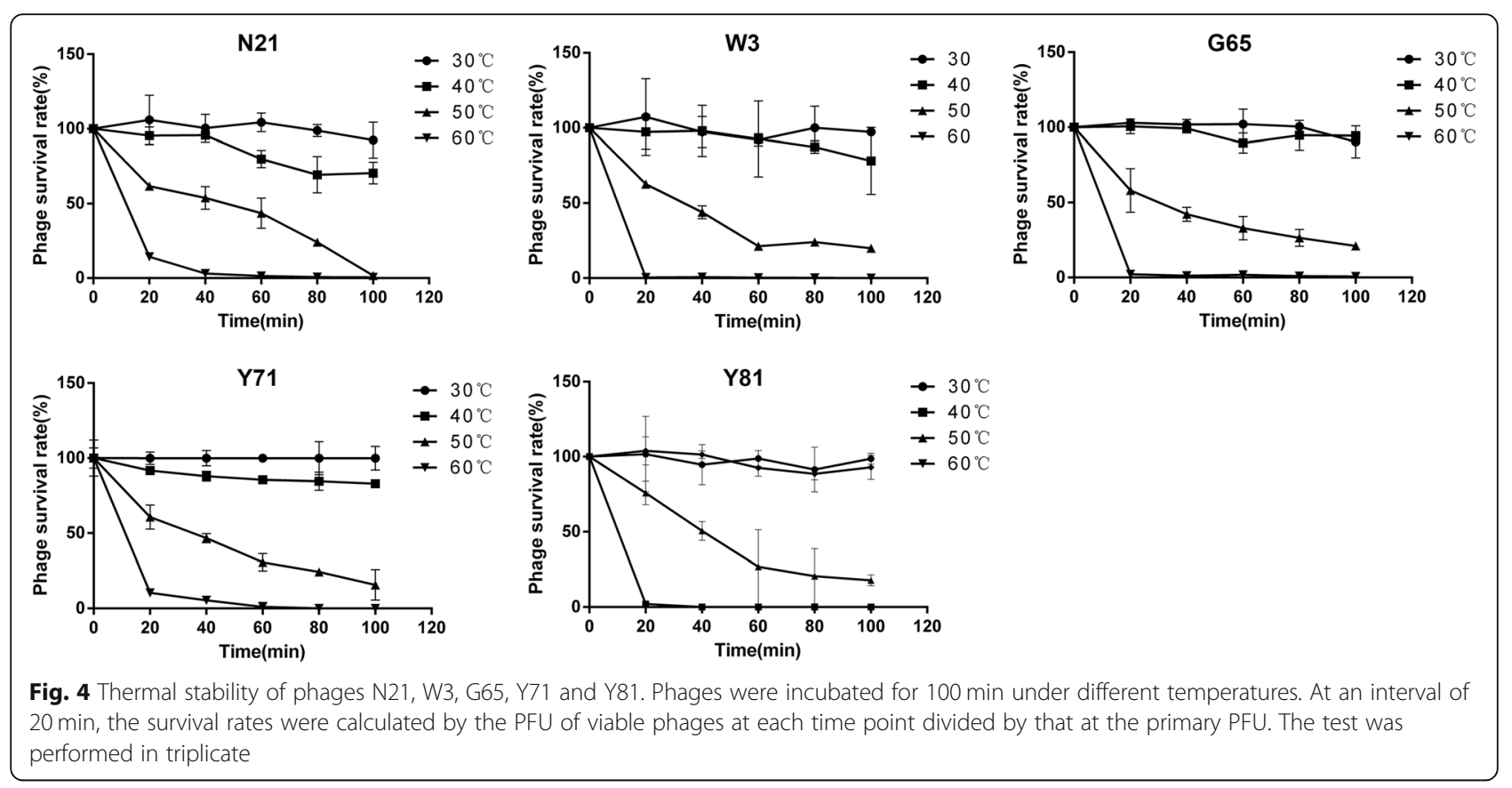

convenient and important criterion for the bacteriophage classification [27]. In this study, TEM analyses indicated that N21, W3 and G65 virions resembled a novel virulent Myoviridae phage, AHP-1, recently identified [28], consisting of an icosahedral head, and a contractile tail with a base plate and six long fibers, but with no "stars" or "prongs" at the base of the tail [29]. Although the virions of Ackermannviridae and Herelleviridae have been also reported to be of myovirus morphology, the tail spikes are the morphological markers of the family Ackermannviridae [29, 30] and the phages of the family Herelleviridae always infect members of the phylum Firmicutes [31]. Therefore, phages N21, W3 and G65 are actually more closely related to the family Myoviridae. At present, most bacteriophages reported against Aeromonas spp. have been characterized as tailed phages, and the family Myoviridae were found to be the majority [22, 23, 32, 33]. For intance, Ackermann [23] indicated that 33 of 43 Aeromonas phages investigated belonged to the Myoviridae family. Also, several Aeromonas phages belonging to the family Podoviridae have been

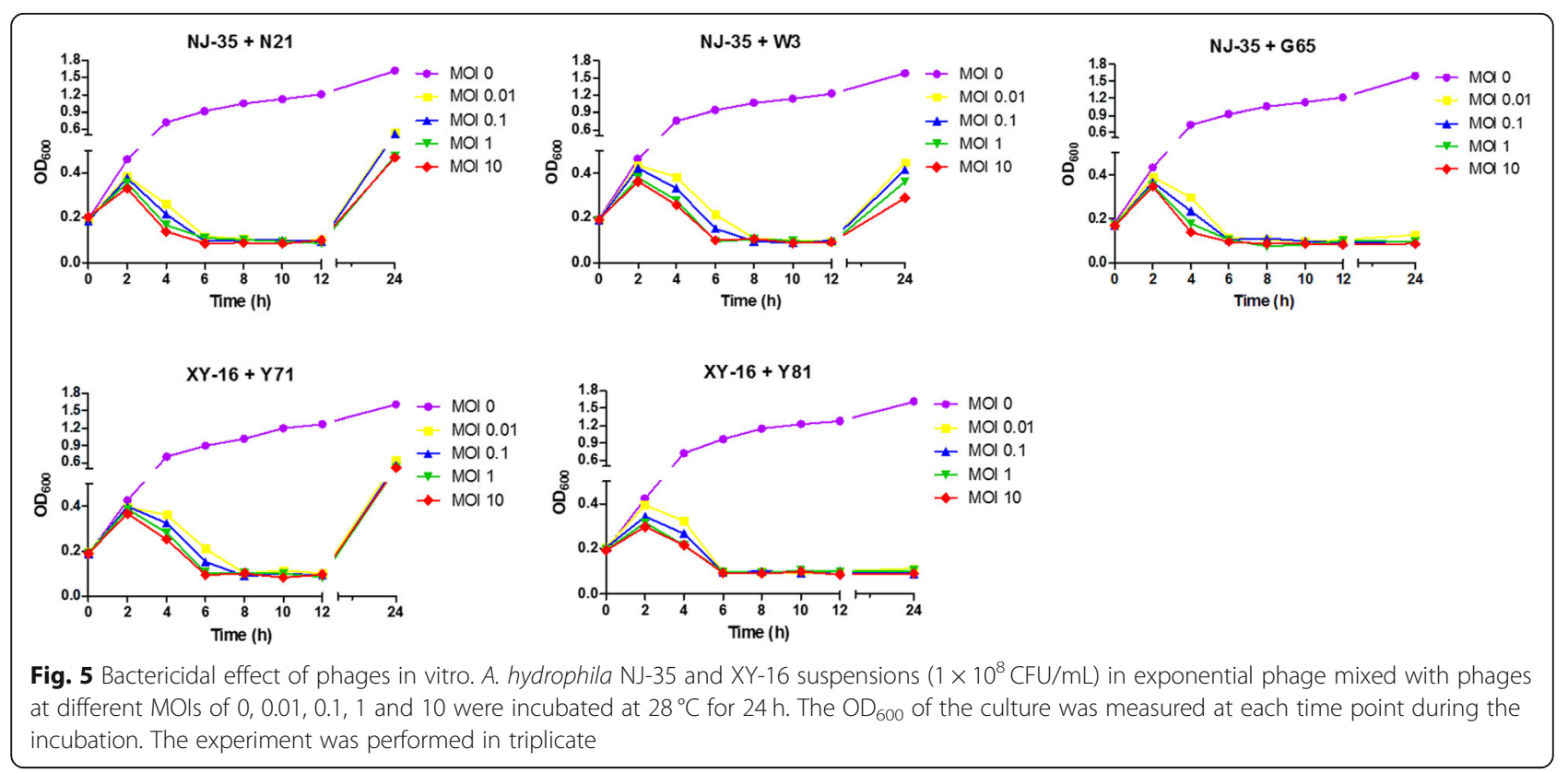


A. hydrophila NJ-35

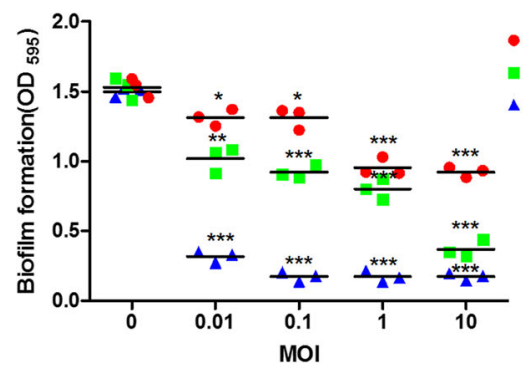

A. hydrophila XY-16

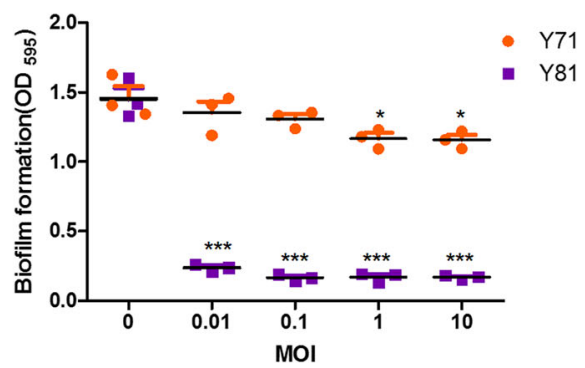

Fig. 6 Effect of phages on preventing formation of biofilm. The biofilm formation ability was measured in A. hydrophila NJ-35 co-incubated with phage N21, W3 of G65 (A), and A. hydrophila XY-16 co-incubated with phage Y71 or Y81 (B) at an MOl of 0.01, 0.1, 1 and 10, using crystal violet staining method. A bacterial culture with no phage served as a control. Data are shown as the mean \pm SD from the triplicate experiments. ${ }^{* * *} P<$ 0.001 , ${ }^{*} P<0.01$ or ${ }^{*} P<0.05$ indicates a significant difference between this group and the control with no phage treatment

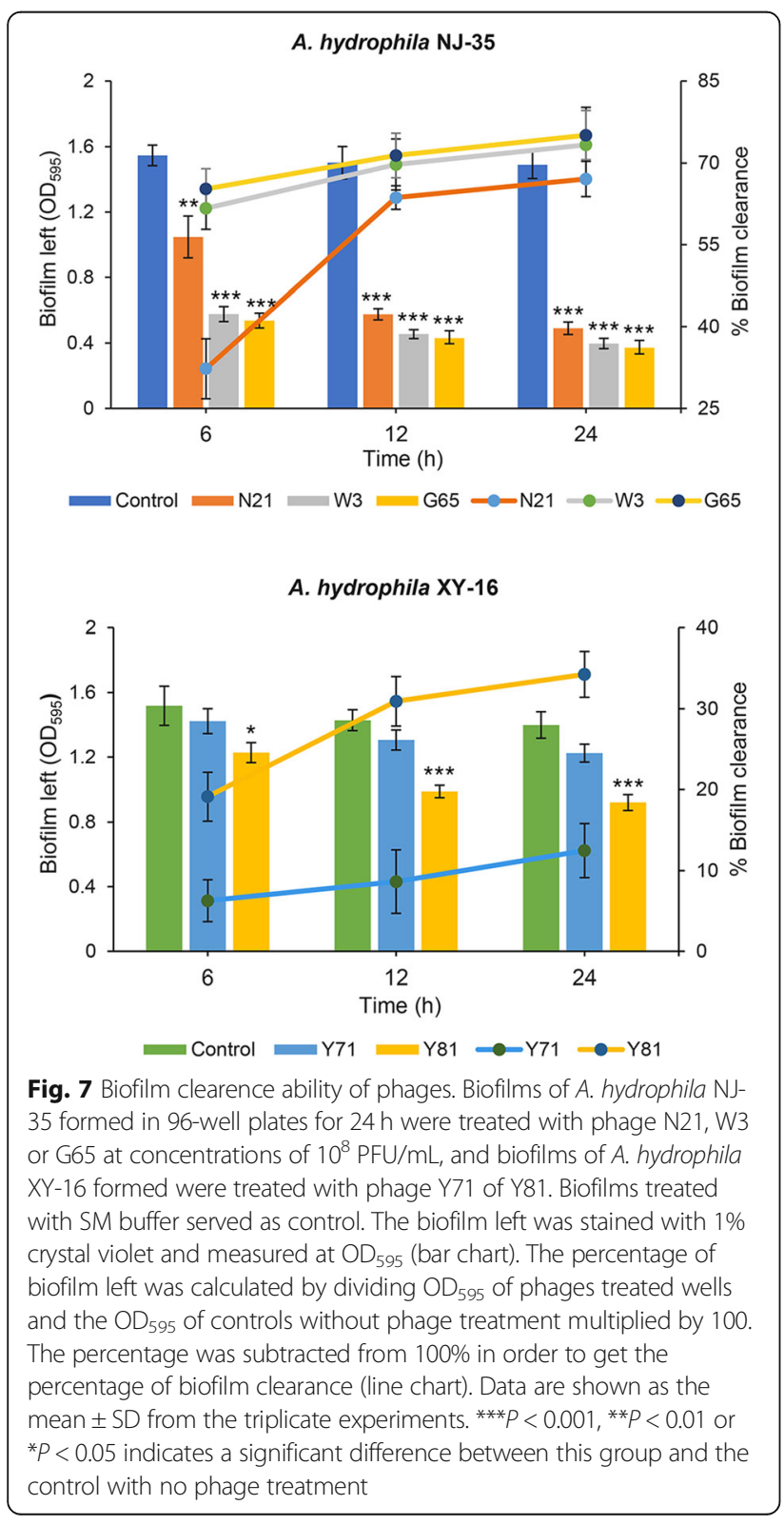

isolated and characterized [34-36]. Phage Y71 and Y81 isolated in this study, possessing an icosahedral head with a short non-contractile tail typical of the Podoviridae, were tentatively classified as members of this family.

Desired properties for efficient phage therapy may depend on phage virulence, host range, latent period, obligately lytic property and so on. Broad host range usually exhibites great advantages in combating multiple pathogen infections. In general, phage showed narrow host specificity that only infect its indicator host [37, 38], although there are also some Aeromonas bacteriophages that show wide host spectrum [39]. Our study revealed that the phages isolated here had relatively broad spectrum of infectivity against $A$. hydrophila and showed the potential to infect $A$. caviae, $A$. veronii and $A$. bestiarum. Short latent period and large burst size are essential features for highly effective phages serving as as therapeutic agents [40]. Previous study demonstrated that a T4-like bacteriophage BPA6 infecting A. hydrophila had a burst size of 244 phage particles per cell with approximately $10 \mathrm{~min}$ of latent period [41]. Similar latent periods and burst sizes of the five phages were observed in our study. Moreover, it is commonly accepted that lytic phages are preferred over temperate phages for phage therapy purpose, although advances in sequencing technologies and synthetic biology are making the temperate phages a great potential for the application of therapy against bacterial infections [42]. Traditionally, the formation of clear plaques has always been used as a presumptive determination of a lytic phage while turbid plaques or especially turbid-centered plaques may imply a temperate phage [43, 44]. All of the five phages isolated in this study form uniform and clear plaques on the $A$. hydrophila strain, suggesting that the phages are most likely to be lytic rather than temperate phages. However, this is not always definitive and further genome-based characterizations of the phages are needed to verify this. Additionally, our phages, being more resistant to alkali than acid condition, showed a broad $\mathrm{pH}$ 

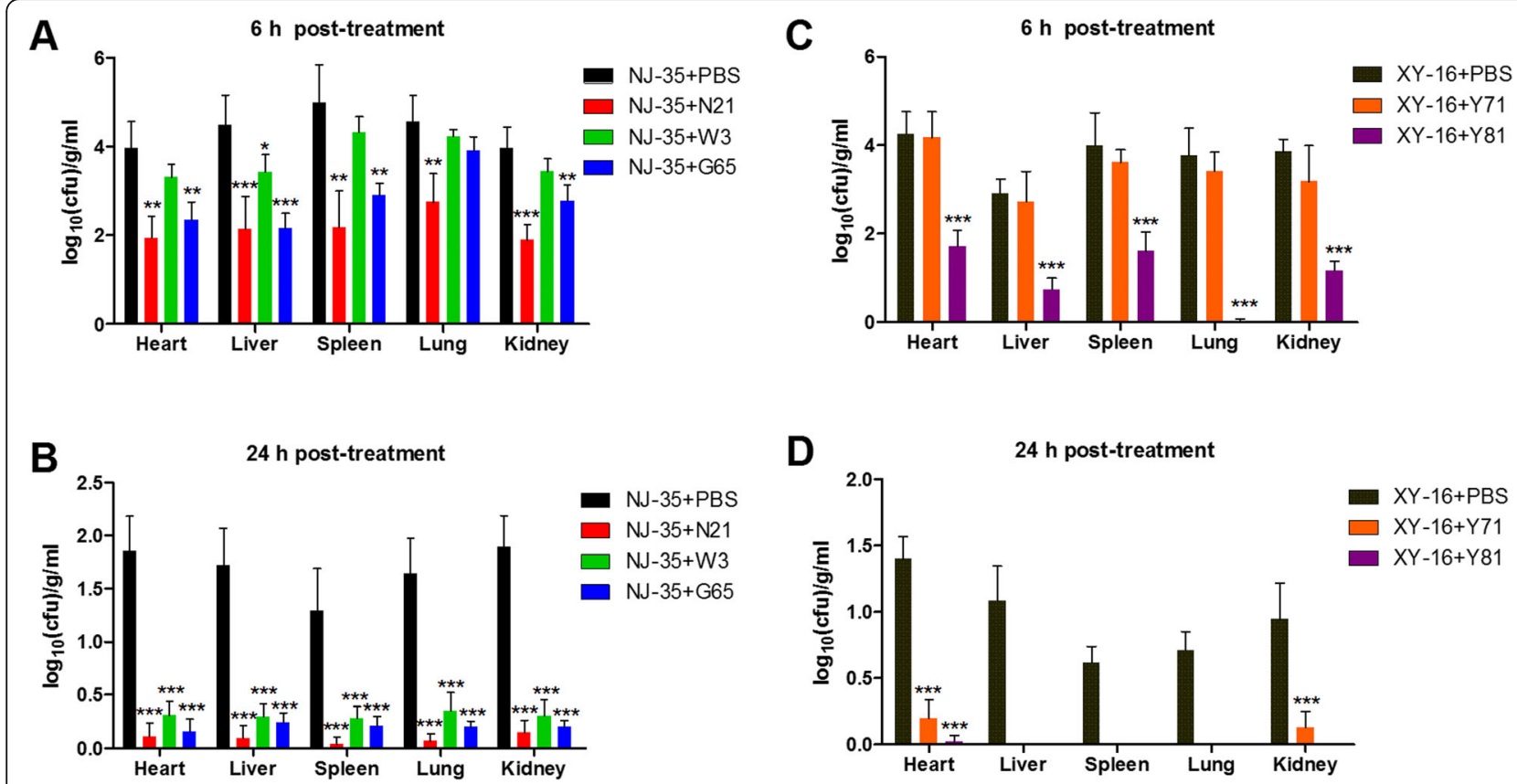

Fig. 8 Therapy treatment of phages on A. hydrophila infection in mice model. Bacterial loads in the tissues of mice infected with A. hydrophila NJ35 after treating with phages N21, W3 or G65 at the MOl of 1 for $6 \mathrm{~h}$ (A) and $24 \mathrm{~h}$ (B). Bacterial loads in the tissues of mice infected with $A$. hydrophila XY-16 after treating with phages $Y 71$ or Y81 for $6 \mathrm{~h}$ (C) and $24 \mathrm{~h}$ (D). Mice treated with PBS after infecting with $A$. hydrophila served as the control. Data are shown as the mean \pm SD from five mice in three independ experiments. ${ }^{* *} P<0.001,{ }^{*} P<0.01$ or ${ }^{*} P<0.05$ indicates a significant difference between this group and the control with no phage treatment

tolerance compared to most isolated phages [38, 45-47]. Besides, the phages were found to be relatively stable up to $40^{\circ} \mathrm{C}$. The high $\mathrm{pH}$ and thermal resistance made the phages be potential for possible treatment of $A$. hydrophila infection or contamination in the diverse physicochemical environments.

Expectively, phage therapy in mice model resulted in a decreased bacterial loads in tissues compared to the control groups after treating for $6 \mathrm{~h}$, suggesting a potential role for phages in controlling $A$. hydrophila infection. The therapy effect was found to be time-dependent, and few bacteria were detected after $24 \mathrm{~h}$ treatment by any of the phages. It should be noted that for phage N21, W3, or Y71, the bacteriolytic activity in vivo was different from that in vitro, which indicated that bacterial number rapidly decreased to the minimum at $6 \mathrm{~h}$ after coculture, but began to rise after $12 \mathrm{~h}$. A reason for this might be the appearance of phageresistant variants after phage treatment in vitro. Although the emergence of phage-resistant bacteria is typically low as phages are host-specific and self-dosing, it cannot be avoided since it is a natural mechanism of bacteria-virus co-evolution [48]. This phenomenon can occur in phage treatments both in vitro and in vivo $[22,49,50]$. Nevertheless, it has been reported that the appearance of phageresistant mutants does not affect the effectiveness of therapy in vivo, where the immune system may play a crucial role in the efficiency of phage therapy, especially that neutrophil-phage synergy was essential for the efficient elimination of both phage-sensitive and emergent phageresistant variants [51]. Additionally, to minimize the potential for the development of resistance, a combination of phages with antibiotics might be required, since there is usually no cross-resistance with antibiotics [52]. Besides, when combined with antibiotics, phages are likely to enhance the absorption of antibiotics into bacterial cells [5356]. Further study is required to evaluate the effectiveness of the combining phages with antibiotics in the treatment of $A$. hydrophila infection. In this study, we have not detected phage titres in all organs. In this regard, it would be interesting to determine if the phages localised to the high bacterial titre at infection sites.

In aquatic environments, biofilm formation plays important roles in the survival and pathogenicity of pathogens [57]. The extracellular biofilm matrix serves as a scaffold that protects the bacteria encased in the matrix from various harmful environment including antimicrobial agents and cellular host defenses [58]. Biofilm formation is a major barrier to the current treatment method relying on antibiotics. Although there have been several studies on controlling Aeromonas spp. using bacteriophages [22, 37, 59], no reports are available regarding phages that can control biofilm formation of $A$. hydrophila. In this study, phages G65 and Y81 showed excellent effect on preventing formation of biofilm at 24 
$\mathrm{h}$ after coculture even at a small MOI of 0.01 , while relatively poor performance was observed in the other three phages. Additionally, almost no bacterial growth was detected at $24 \mathrm{~h}$ after treated with phages G65 or Y81. To clear whether the biofilm decrease depends on the phage activity to digest the biofilm or the reduction of bacterial viability, we detected the activities of the five phages on the biofilm formation of $A$. hydrophila XX-58 (accession number of $\operatorname{gyr} B$ gene: JX025795.1), which was determined to be not susceptible to the infection of the phages in this study. The data indicated that the biofilm formation of XX-58 was not affected by the phage activity (Additional file 1). Our results suggest that the diverse roles of the five phages in preventing biofilm formation were associated with their killing effect on the viable bacterial cells, not with the digestion of the biofilm. Also, we found that the biofilm inhibition of different phages require different MOIs, which is probably owing to the fact that MOI is another major factor determining phage's ability to adsorb host cells in addition to receptors [60].

The phages G65, W3 and N21 reduced mature biofilm for more than $60 \%$ after treating for $24 \mathrm{~h}$. Although phage Y81 showed considerable inhibition effect on biofilm formation, its removal effect on mature biofilm was very low. Interestingly, phages N21 and Y71 behaved similarly in terms of bacteriolytic activities and biofilm inhibiting effect but quite differently in disaggregation of biofilm. As the nutritional and metabolic states as well as phage receptors of bacterial cells in attached state will be different from those in planktonic culture [61], it is not surprising that phages which exhibit poor inhibition effect on bacterial growth and biofilm formation can have high lytic activity to attached bacteria. Although production of structured extracellular polymers of biofilm, in some cases, provides a physical barrier between phages and their receptors, many biofilms have an open structure with fluid-filled channels and pores that would allow the phages access to the bacteria within biofilms $[61,62]$. Therefore, we speculate that the different removal efficiency of five phages to the biofilm might be linked to the biofilm structures of $A$. hydrophila NJ-35 and XY-16. Additionally, some phages can even produce polysaccharide depolymerases to degrade the extracellular matrix, allowing phages to come in contact with the encased bacteria [63]. For instance, Pseudomonas spp. phage F116 produces an alginate lyase that can reduce the viscosity of the alginate exopolysaccharide and promote phages to penetrate the alginate matrix and reach the bacterial surface [64]. Thus, diverse antibiofilm efficacy of the five phages investigated in this study may also be due to the different activities of enzymes that can degrade exopolysaccharides. In addition, phages N21 and G65 displayed semitransparent halos around phage plaques on the lawns of host bacteria, and halo formation has been proposed to play important roles in exopolysaccharide depolymerization and biofilm degradation $[65,66]$. This led us to speculate the halo formation of phage G65 and N21 might be associated with their efficient biofilm removing ability. Nevertheless, this hypothesis remains to be defined in future studies.

\section{Conclusions}

In this study, five A. hydrophila phages were isolated, with three belonging to family Myoviridae and two belonging to family Podoviridae morphologically. All of the five phages have broad host ranges, low letent periods, wide $\mathrm{pH}$ and thermal tolerance, and effective treatment of A. hydrophila infection. More importantly, several phages exhibited varying abilities to prevent and remove A. hydrophila biofilm. This study provides a basis for therapeutic applications of phages to control A. hydrophila infection.

\section{Methods}

\section{Bacterial strains and growth conditions}

Two epidemic strains of high virulence isolated from diseased crucian carp, A. hydrophila NJ-35 (accession number: CP006870.1) from Nanjing, China in 2010 and XY-16 (accession number of gyrB gene: JX025797.1) from Xinyi, China in 2009 [67, 68], were used for phage isolation. An additional 203 Aeromonas strains, including $73 \mathrm{~A}$. hydrophila, $85 \mathrm{~A}$. veronii, $12 \mathrm{~A}$. caviae, $1 \mathrm{~A}$. bestiarum, 12 A. sobria, 10 A. media, 3 A. salmonicida, 3 $A$. jandaei and $4 A$. aquariorum were used for host range analysis. All bacterial strains were routinely cultured in Luria Bertani (LB) broth (Difco/Becton Dickinson) at $28^{\circ} \mathrm{C}$ with shaking at $180 \mathrm{rpm}$. All Aeromonas strains used in this study are listed in Table 1.

\section{Phage isolation, purification and propagation}

A. hydrophila strains NJ-35 and XY-16 were used as indicator hosts for phages. Ten water samples were collected from ponds, sewage and rivers in Nanjing. The samples were centrifuged at $4000 \mathrm{~g}$ for $30 \mathrm{~min}$ and the supernatants were filtered through $0.22-\mu \mathrm{m}$ membrane filters. A $10 \mathrm{~mL}$ of the supernatant was added into 20 $\mathrm{mL}$ of $3 \times \mathrm{LB}$ broth, and $1 \mathrm{~mL}$ cultures of NJ-35 or XY16 (late logarithmic phase) were used to inoculate the mixture. After adding $5 \mathrm{M} \mathrm{CaCl}_{2}$ to a final concentration of $0.1 \mathrm{mM}$, the phages were enriched by culturing for 14 h at $28^{\circ} \mathrm{C}$. A $3 \mathrm{~mL}$ of the culture was added to a $5 \mathrm{~mL}$ LB broth, followed by the addition of chloroform with a final concentration of $3 \%$, vigorously shaken for $2 \mathrm{~min}$. After static layering, $1 \mathrm{~mL}$ of the supernatant was filtered through a $0.22-\mu \mathrm{m}$ filter. To confirm the presence of the lytic phage in the fltrate, the double-layer agar method 
[69] was performed using the filtrate. After incubating at $28^{\circ} \mathrm{C}$ for $8 \mathrm{~h}$, a single plaque was picked up with a sterile pipette tip into LB broth with the addition of host bacteria. After proliferation, the phages were purified several times using the double-layer agar method.

\section{Host range}

The host range of the harvested phages was determined using a spot assay. Aeromonas strains were spread evenly on the LB agar plate. Five microliters of the phage cultures of $10^{8} \mathrm{PFU} / \mathrm{mL}$ were dropped onto the overlaid top agar. After cultured for $12 \mathrm{~h}$ at $28^{\circ} \mathrm{C}$, the presence or absence of a lysis zone was observed.

\section{TEM analysis}

The phages were cultured at $28^{\circ} \mathrm{C}$ for $8-10 \mathrm{~h}$ using the double-layer plates. A plate with plenty of plaques whose edges were faintly visible was added with $2 \mathrm{~mL}$ of sterilized double deionized water $\left(\mathrm{ddH}_{2} \mathrm{O}\right)$. The plate was shaken horizontally for $5 \mathrm{~min}$ to fully wash off the phages. Suspensions in the plate were centrifuged at $6000 \mathrm{~g}$ for $5 \mathrm{~min}$. For TEM analysis, $15 \mu \mathrm{L}$ of the phage supernatant was spotted on a carbon/Formvar-coated 200-mesh copper grid (Ted-Pella Inc., CA, USA). After $3 \mathrm{~min}$, the suspension was removed by filter paper and the grid was baked under incandescent light for 5-10 s. The phages were negatively stained with $2 \%$ uranyl acetate for $1 \mathrm{~min}$. Excess dye was removed by the filter paper and the grid was dried under an incandescent lamp. The morphology of the phage was imaged by TEM (H-7650, Hitachi, Japan) operated at $80 \mathrm{kV}$. Phage dimensions were calculated by measuring the dimensions of five independent phages.

\section{Determination of optimal MOI}

The optimal MOI is the ratio of the number of phages to that of host bacteria present in a defined space that is best for phage proliferation to obtain maximum titers. $A$. hydrophila strains grown to the log phase were washed three times with PBS and adjusted to corresponding densities of $10^{5}, 10^{6}, 10^{7}$ and $10^{8} \mathrm{CFU} / \mathrm{mL}$, respectively. The phages and bacteria were mixed with MOIs of 100 , $10,1,0.1,0.01,0.001$ and 0.0001 , respectively. After incubation for $2 \mathrm{~h}$ at $28^{\circ} \mathrm{C}$, the phage titers were measured by the double-layer agar method.

\section{One-step growth curve}

One-step growth experiment was performed according to the method described by Adams [43]. A. hydrophila NJ-35 and XY-16 were cultured in $1 \mathrm{~mL} \mathrm{LB}$ broth to $\mathrm{OD}_{600}$ of $0.5-0.6$ and collected by centrifugation. The cells were resuspended with $0.9 \mathrm{~mL}$ fresh $\mathrm{LB}$ broth and mixed with $0.1 \mathrm{ml}$ phage solutions $\left(1 \times 10^{8} \mathrm{PFU} / \mathrm{ml}\right)$. The phages were allowed to absorb for $5 \mathrm{~min}$ and then centrifuged at $13,000 \mathrm{~g}$ for $1 \mathrm{~min}$ to remove free phage particles. After discarding the supernatants, the phageinfected bacterial pellets were resuspended in $50 \mathrm{~mL}$ of prewarmed LB broth and the cultures were continuously incubated at $28^{\circ} \mathrm{C}$. At an interval of $5 \mathrm{~min}$, samples were harvested and phage titers were immediately determined by the double-layer agar method. The burst size of phages was calculated by dividing the final titer of released phage particles by the initial count of infected bacterial cells.

\section{$\mathrm{pH}$ and thermal stability assays}

For $\mathrm{pH}$ stability tests, $100 \mu \mathrm{L}$ phage suspension $(1.0 \times$ $10^{7} \mathrm{PFU} / \mathrm{mL}$ ) was used to inoculate $900 \mu \mathrm{L}$ physiological saline adjusted to $\mathrm{pH}$ values of $3 \sim 12$ with $\mathrm{NaOH}$ or $\mathrm{HCl}$. The mixtures were incubated at $28^{\circ} \mathrm{C}$ for $2 \mathrm{~h}$ and aliquots were taken to measure the titers of phages at different $\mathrm{pH}$ values. For thermal stability tests, $2 \mathrm{~mL}$ phage suspension $\left(1.0 \times 10^{7} \mathrm{PFU} / \mathrm{mL}\right)$ was incubated at $30^{\circ} \mathrm{C}, 40^{\circ} \mathrm{C}, 50^{\circ} \mathrm{C}$, and $60^{\circ} \mathrm{C}$. At an interval of $20 \mathrm{~min}$, $100-\mu \mathrm{L}$ aliquots were collected until $100 \mathrm{~min}$. Survived phages were counted and the survival rates were calculated by the PFU at each time point divided by that at the primary PFU. All tests were performed in triplicate.

\section{Phage killing assay in vitro}

Bacterial killing assays were conducted for the phages as previously described [70]. Briefly, A. hydrophila NJ-35 and XY-16 suspensions $\left(1 \times 10^{8} \mathrm{CFU} / \mathrm{mL}\right)$ in exponential period were mixed with an equal volume of phages at different MOIs of $0.01,0.1,1$, and 10, respectively, followed by incubation at $28^{\circ} \mathrm{C}$ for $24 \mathrm{~h}$. A. hydrophila cultures mixed with LB broth served as positive controls. The absorbances (OD600) of the cultures were measured at each time point. The experiment was performed in triplicate.

\section{Biofilm formation assay}

A. hydrophila strains were cultured in LB broth to logarithmic period and then normalized to $1 \times 10^{6} \mathrm{CFU} / \mathrm{mL}$. The suspensions were mixed with equal volume of phages with the MOI of $0.01,0.1,0,1$, and 10 , respectively. Two hundred microliters of the mixtures were added into each well of the 96-well plates. Each treatment was performed in eight replicates. Fresh LB broth served as a blank control. Then the plates were incubated at $28^{\circ} \mathrm{C}$ for $24 \mathrm{~h}$. Next, the culture supernatants were discarded and the plates were washed three times with sterile PBS to remove all planktonic cells. Biofilms formed in each well were fixed with $200 \mu \mathrm{L}$ of $99 \%$ (vol/ vol) methanol for $15 \mathrm{~min}$. After drying, biofilms were stained with $1 \%$ crystal violet for $10 \mathrm{~min}$. Then the wells were washed with distilled water to remove unbound dye. Crystal violet was dissolved in $200 \mu \mathrm{L}$ of $95 \%$ ethanol for $10 \mathrm{~min}$ and the absorbance was measured at 595 
$\mathrm{nm}\left(\mathrm{OD}_{595}\right)$ using a micro-plate reader (Tecan, Switzerland).

\section{Biofilm clearance assay}

A. hydrophila strains were cultured in LB medium to logarithmic period and then normalized to $\mathrm{OD}_{600}$ of 1.0. The suspensions were inoculated to LB media $(200 \mu \mathrm{L}$ per well) in 96-well plates at a ratio of 1:1000. The plates were incubated at $28^{\circ} \mathrm{C}$ for $24 \mathrm{~h}$ without shaking. After removing all planktonic cells, each well were treated with $200 \mu \mathrm{L}$ phage dilution of $1 \times 10^{8} \mathrm{PFU} / \mathrm{mL}$ with sodium chloride-magnesium sulfate (SM) buffer $(100 \mathrm{mM}$ $\mathrm{NaCl}, 50 \mathrm{mM}$ Tris pH 7.5, and $10 \mathrm{mM} \mathrm{MgSO}_{4}$ ) for $6 \mathrm{~h}$, $12 \mathrm{~h}$, and $24 \mathrm{~h}$. Biofilms treated with SM buffer served as the control. The microplates were then washed twice with PBS and the biofilms left were stained and measured by crystal violet method. The $\mathrm{OD}_{595}$ absorbance of each well was measured using a micro-plate reader. The percentage of biofilm left was calculated by dividing $\mathrm{OD}_{595}$ of phage treated wells and the $\mathrm{OD}_{595}$ of controls without phage treatment multiplied by 100 . The percentage was subtracted from $100 \%$ in order to get the percentage of biofilm clearance.

\section{Phage therapy assay in mice model}

The animal experiment was performed in accordance with the animal welfare standards, complied with the guidelines of the Experimental Animal Welfare Ethics Committee, Chinese Association for Laboratory Animal Sciences, and was approved by the Ethical Committee for Animal Experiments of Nanjing Agricultural University, China (approval number: SYXK(Su) 2017-0007). Six-week-old female Institute of Cancer Research (ICR) mice (body weight, $18 \pm 2 \mathrm{~g}$ ) were purchased from the Experimental Animal Center of Yangzhou University and raised in the Experimental Animal Center of College of Veterinary Medicine, Nanjin Agricultural University under specific-pathogen-free (SPF) conditions. The dose of $A$. hydrophila used in this study was chosen on the basis of a preliminary study that the mice were expected to show obvious clinical signs but no death. A. hydrophila NJ-35 and XY-16 grown to log phase were washed three times with PBS and adjusted to $5 \times 10^{7}$ and $1 \times$ $10^{8} \mathrm{CFU} / \mathrm{mL}$, respectively. For phage therapy assay, a total of 120 mice were randomly divided into three groups and housed in cages (5 mice per cage). Feed and water were allowed ad libitum. To evaluate treatment efficiency of phages in A. hydrophila NJ-35 infection, 40 mice were intraperitoneally inoculated with $100 \mu \mathrm{L}$ of bacterial suspension of A. hydrophila NJ-35; after 30 $\mathrm{min}$, the infection group of 10 mice were then intraperitoneally injected with $100 \mu \mathrm{L}$ of sterile PBS, while each 10 out of the other 30 mice in the treatment group were injected with $100 \mu \mathrm{L}$ of phages N21, W3 or G65 at the
MOI of 1 . The blank control group of 30 mice were intraperitoneally injected with $100 \mu \mathrm{L}$ of sterile PBS, followed by injecting $100 \mu \mathrm{L}$ of each of the phage suspensions. Similarly, 50 mice were used to determine the therapy effect of phages Y71 and Y81 on A. hydrophila $\mathrm{XY}-16$ infection. After $6 \mathrm{~h}$ and $24 \mathrm{~h}$, five mice in each treatment were euthanized by $\mathrm{CO}_{2}$, respectively. Hearts, livers, spleens, lungs and kidneys were aseptically removed from the mice, weighed, added to $1 \mathrm{~mL}$ of sterilized PBS, homogenized using a tissue homogenizer (Bioprep-24, Allsheng, Hangzhou, China), and then 10fold serially diluted in PBS. Bacterial loads in tissues were determined by plating the dilutions on LB plates. The results are expressed as the numbers of $\mathrm{CFU} / \mathrm{g}$ tissue.

\section{Statistical analyses}

Data were collected and analyzed using GraphPad Prism version 5 software. A $t$-test was used to analyze the difference between the phage-treatment groups and the control groups. Error bars presented in the figures represent standard deviations of the means of three replicate experiments. A $P$-value $<0.05$ was considered as a significant difference.

\section{Supplementary information}

Supplementary information accompanies this paper at https://doi.org/10. 1186/s12866-020-01811-w.

Additional file 1. Phage activity on the biofilm formation of $A$. hydrophila XX-58. The biofilm formation ability of $A$. hydrophila XX-58, a bactreiophage-resitant strain, co-incubated with phage N21, W3, G65, Y71 or $Y 81$ at an $\mathrm{MOI}$ of $0.01,0.1,1$ and 10 was measured using crystal violet staining method. Data are shown as the mean \pm SD from the triplicate experiments.

\section{Abbreviations}

MDR: Multidrug resistance; UPEC: Uropathogenic Escherichia coli; LB: Luria Bertani broth; MOI: Multiplicity of infection; TEM: Transmission electron microscopy; CFU: Colony-forming units; PFU: Plaque forming units; PBS: Phosphate buffer saline; SM: Sodium chloride-magnesium sulfate; SPF: Specific-pathogen-free; ICR: Institute of Cancer Research

\section{Acknowledgements}

The authors thank Meng Hu and Yafeng Wu for providing parts of the Aeromonas strains.

\section{Authors' contributions}

$J \mathrm{~L}$ analyzed the data and wrote the manuscript; SG and $J \mathrm{~L}$ carried out most of the experiments; YD and CL participated in the design of the study and performed the statistical analysis. YL provided expertise and conceived the study. All authors read and approved the final manuscript.

\section{Funding}

This study was funded by the National Key R \& D Program of China (2019YFC1605402), Three New Aquatic Projects in Jiangsu Province (D2017-31), Independent Innovation Fund of Agricultural Science and Technology in Jiangsu Province (CX(17)2027, CX(18)2011) and Priority Academic Program Development of Jiangsu Higher Education Institutions (PAPD). The funders had no role in the design of the study, data collection and analysis, or preparation of the manuscript. 


\section{Availability of data and materials}

All data generated or analyzed during current study are available from the corresponding author on reasonable request.

\section{Ethics approval and consent to participate}

The animal experiment was performed in accordance with the animal welfare standards, complied with the guidelines of the Experimental Animal Welfare Ethics Committee, Chinese Association for Laboratory Animal Sciences, and was approved by the Ethical Committee for Animal Experiments of Nanjing Agricultural University, China (approval number: SYXK(Su) 2017-0007).

\section{Consent for publication}

Not applicable.

\section{Competing interests}

The authors declare that they have no competing interests.

\section{Author details}

'Joint International Research Laboratory of Animal Health and Food Safety, College of Veterinary Medicine, Nanjing Agricultural University, Nanjing 210095, China. ${ }^{2}$ Sucheng District Animal Husbandry and Veterinary Station, Suqian 223800, China.

Received: 14 January 2020 Accepted: 4 May 2020

Published online: 01 June 2020

\section{References}

1. Janda JM, Abbott SL. The genus Aeromonas: taxonomy, pathogenicity, and infection. Clin Microbiol Rev. 2010;23(1):35-73.

2. Galindo CL, Gutierrez C Jr, Chopra AK. Potential involvement of galectin-3 and SNAP23 in Aeromonas hydrophila cytotoxic enterotoxin-induced host cell apoptosis. Microb Pathog. 2006;40(2):56-68.

3. Van Boeckel TP, Brower C, Gilbert M, Grenfell BT, Levin SA, Robinson TP, Teillant A, Laxminarayan R. Global trends in antimicrobial use in food animals. P Natl Acad Sci U S A. 2015;112(18):5649-54.

4. Van Boeckel TP, Pires J, Silvester R, Zhao C, Song J, Criscuolo NG, Gilbert M Bonhoeffer S, Laxminarayan R. Global trends in antimicrobial resistance in animals in low- and middle-income countries. Science. 2019;365:6459.

5. Martinez JL. Environmental pollution by antibiotics and by antibiotic resistance determinants. Environ Pollut. 2009;157(11):2893-902.

6. Elbehiry A, Marzouk E, Abdeen E, Al-Dubaib M, Alsayeqh A, Ibrahem M, Hamada M, Alenzi A, Moussa I, Hemeg HA. Proteomic characterization and discrimination of Aeromonas species recovered from meat and water samples with a spotlight on the antimicrobial resistance of Aeromonas hydrophila. Microbiologyopen. 2019;8(11):e782.

7. Liu X, Steele JC, Meng XZ. Usage, residue, and human health risk of antibiotics in Chinese aquaculture: a review. Environ Pollut. 2017;223:161-9.

8. Stratev D, Odeyemi OA. Antimicrobial resistance of Aeromonas hydrophila isolated from different food sources: a mini-review. J Infect Public Health. 2016;9(5):535-44.

9. Vivekanandhan G, Savithamani K, Hatha AA, Lakshmanaperumalsamy P. Antibiotic resistance of Aeromonas hydrophila isolated from marketed fish and prawn of South India. Int J Food Microbiol. 2002;76(1-2):165-8.

10. De Silva BCJ, Hossain S, Dahanayake PS, Heo GJ. Aeromonas spp. from marketed Yesso scallop (Patinopecten yessoensis): molecular characterization, phylogenetic analysis, virulence properties and antimicrobial susceptibility. J Appl Microbiol. 2019;126(1):288-99.

11. Hossain S, De Silva BCJ, Dahanayake PS, Heo GJ. Characterization of virulence properties and multi-drug resistance profiles in motile Aeromonas spp. isolated from zebrafish (Danio rerio). Lett Appl Microbiol. 2018;67(6): 598-605.

12. Barker J, Brown MR, Collier PJ, Farrell I, Gilbert P. Relationship between Legionella pneumophila and Acanthamoeba polyphaga: physiological status and susceptibility to chemical inactivation. Appl Environ Microbiol. 1992; 58(8):2420-5.

13. Del Castillo CS, Hikima J, Jang HB, Nho SW, Jung TS, Wongtavatchai J, Kondo H, Hirono I, Takeyama H, Aoki T. Comparative sequence analysis of a multidrug-resistant plasmid from Aeromonas hydrophila. Antimicrob Agents Chemother. 2013;57(1):120-9.
14. Lebeaux D, Ghigo JM, Beloin C. Biofilm-related infections: bridging the gap between clinical management and fundamental aspects of recalcitrance toward antibiotics. Microbiol Mol Biol Rev. 2014;78(3):510-43.

15. Cai W, Arias CR. Biofilm formation on aquaculture substrates by selected bacterial fish pathogens. J Aquat Anim Health. 2017;29(2):95-104.

16. Hall CW, Mah TF. Molecular mechanisms of biofilm-based antibiotic resistance and tolerance in pathogenic bacteria. FEMS Microbiol Rev. 2017; 41(3):276-301.

17. Mah TF, Pitts B, Pellock B, Walker GC, Stewart PS, O'Toole GA. A genetic basis for Pseudomonas aeruginosa biofilm antibiotic resistance. Nature. 2003. 426(6964):306-10.

18. Abedon ST, Thomas-Abedon C. Phage therapy pharmacology. Curr Pharm Biotechno. 2010;11(1):28-47.

19. Nishikawa H, Yasuda M, Uchiyama J, Rashel M, Maeda Y, Takemura I, Sugihara S, Ujihara T, Shimizu Y, Shuin T, et al. T-even-related bacteriophages as candidates for treatment of Escherichia coli urinary tract infections. Arch Virol. 2008;153(3):507-15.

20. Matsuzaki S, Yasuda M, Nishikawa H, Kuroda M, Ujihara T, Shuin T, Shen Y, Jin Z, Fujimoto S, Nasimuzzaman MD, et al. Experimental protection of mice against lethal Staphylococcus aureus infection by novel bacteriophage phi MR11. J Infect Dis. 2003;187(4):613-24

21. Jun JW, Kim JH, Shin SP, Han JE, Chai JY, Park SC. Protective effects of the Aeromonas phages pAh1-C and pAh6-C against mass mortality of the cyprinid loach (Misgurnus anguillicaudatus) caused by Aeromonas hydrophila. Aquaculture. 2013;416:289-95.

22. Le TS, Nguyen TH, Vo HP, Doan VC, Nguyen HL, Tran MT, Tran TT, Southgate PC, Kurtboke DI. Protective effects of bacteriophages against Aeromonas hydrophila species causing motile Aeromonas septicemia (MAS) in striped catfish. Antibiotics. 2018;7(1):16.

23. Ackermann HW. 5500 phages examined in the electron microscope. Arch Virol. 2007;152(2):227-43.

24. Tolstoy I, Kropinski AM, Brister JR. Bacteriophage taxonomy: an evolving discipline. Methods Mol Biol. 1693;2018:57-71.

25. Barylski J, Enault F, Dutilh B, Schuller M, Edwards R, Gillis A, Klumpp J, Knezevic P, Krupovic M, Kuhn J, et al. To create one (1) new family, Herelleviridae, in the order Caudovirales; 2018. https://doi.org/10.13140/RG.2.2.20828.23687.

26. Kuhn J, Kropinski A, Anany H, Tolstoy I, Kutter E, Adriaenssens E. To create a new bacteriophage family, Ackermannviridae, containing two (2) new subfamilies including four (4) genera; 2017. https://doi.org/10.13140/RG.2.2. 29173.88800.

27. Ackermann HW, DuBow MS, Jarvis AW, Jones LA, Krylov VN, Maniloff J, Rocourt J, Safferman RS, Schneider J, Seldin L, et al. The species concept and its application to tailed phages. Arch Virol. 1992;124(1-2):69-82.

28. Chandrarathna H, Nikapitiya C, Dananjaya SHS, De Silva BCJ, Heo GJ, De Zoysa M, Lee J. Isolation and characterization of phage AHP-1 and its combined effect with chloramphenicol to control Aeromonas hydrophila. Braz J Microbiol. 2019;5. https://doi.org/10.1007/s42770-019-00178-z.

29. Adriaenssens EM, Ackermann HW, Anany H, Blasdel B, Connerton IF, Goulding D, Griffiths MW, Hooton SP, Kutter EM, Kropinski AM, et al. A suggested new bacteriophage genus: "Viunalikevirus". Arch Virol. 2012; 157(10):2035-46.

30. Day A, Ahn J, Salmond GPC. Jumbo bacteriophages are represented within an increasing diversity of environmental viruses infecting the emerging phytopathogen, Dickeya solani. Front Microbiol. 2018;9:2169.

31. Barylski J, Kropinski AM, Alikhan N-F, Adriaenssens EM, Report Consortium ICTV. ICTV virus taxonomy profile: Herelleviridae. J Gen Virol. 2020; (In Press).

32. UI Haq I, Chaudhry WN, Andleeb S, Qadri I. Isolation and partial characterization of a virulent bacteriophage IHQ1 specific for Aeromonas punctata from stream water. Microb Ecol. 2012;63(4):954-63.

33. Kim JH, Son JS, Choi YJ, Choresca CH, Shin SP, Han JE, Jun JW, Kang DH, Oh C, Heo SJ, et al. Isolation and characterization of a lytic Myoviridae bacteriophage PAS-1 with broad infectivity in Aeromonas salmonicida. Curr Microbiol. 2012;64(5):418-26.

34. Anand T, Bera BC, Virmani N, Vaid RK, Vashisth M, Tripathi BN. Isolation and characterization of a novel, T7-like phage against Aeromonas veronii. Virus Genes. 2018:54(1):160-4.

35. Islam MS, Raz A, Liu Y, Elbassiony KRA, Dong X, Zhou P, Zhou Y, Li J. Complete genome sequence of Aeromonas phage ZPAH7 with halo zones, isolated in China. Microbiol Resour Announc. 2019;8(10):e01678-18.

36. Cao Y, Li S, Wang D, Zhao J, Xu L, Liu H, Lu T, Mou Z. Genomic characterization of a novel virulent phage infecting the Aeromonas 
hydrophila isolated from rainbow trout (Oncorhynchus mykiss). Virus Res. 2019;273:197764.

37. Kim JH, Choresca CH, Shin SP, Han JE, Jun JW, Park SC. Biological control of Aeromonas salmonicida subsp. salmonicida infection in rainbow trout (Oncorhynchus mykiss) using Aeromonas phage PAS-1. Trans Emerg Dis. 2015;62(1):81-6.

38. Nikapitiya C, Dananjaya SHS, Chandrarathna H, Senevirathne A, De Zoysa M, Lee J. Isolation and characterization of multidrug resistance Aeromonas salmonicida subsp. salmonicida and its infecting novel phage ASP-1 from goldfish (Carassius auratus). Indian J Microbiol. 2019;59(2):161-70.

39. Kim JH, Son JS, Choi YJ, Choresca CH Jr, Shin SP, Han JE, Jun JW, Park SC. Complete genome sequence and characterization of a broad-host range T4-like bacteriophage phiAS5 infecting Aeromonas salmonicida subsp. salmonicida. Vet Microbiol. 2012;157(1-2):164-71.

40. Bull JJ, Gill JJ. The habits of highly effective phages: population dynamics as a framework for identifying therapeutic phages. Front Microbiol. 2014;5:618.

41. Anand T, Vaid RK, Bera B, Singh J, Barua S, Virmani N, Rajukumar K, Yadav NK, Nagar D, Singh RK, et al. Isolation of a lytic bacteriophage against virulent Aeromonas hydrophila from an organized equine farm. J Basic Microbiol. 2016;56(4):432-7.

42. Monteiro R, Pires DP, Costa AR, Azeredo J. Phage therapy: going temperate? Trends Microbiol. 2019;27(4):368-78.

43. Adams MH. Bacteriophages. New York: InterScience Publishers; 1959. p. 445-7.

44. Lwoff A. Lysogeny. Bacteriol Rev. 1953;17(4):269-337.

45. Lu L, Cai L, Jiao N, Zhang R. Isolation and characterization of the first phage infecting ecologically important marine bacteria Erythrobacter. Virol J. 2017; 14(1):104.

46. Ben Kahla-Nakbi A, Chaieb K, Bakhrouf A. Investigation of several virulence properties among Vibrio alginolyticus strains isolated from diseased cultured fish in Tunisia. Dis Aquat Orga. 2009;86(1):21-8.

47. Yang $H$, Liang $L$, Lin $S$, Jia $S$. Isolation and characterization of a virulent bacteriophage AB1 of Acinetobacter baumannii. BMC Microbiol. 2010;10:131.

48. Maciejewska B, Olszak T, Drulis-Kawa Z. Applications of bacteriophages versus phage enzymes to combat and cure bacterial infections: an ambitious and also a realistic application? Appl Microbiology Biotechnol. 2018;102(6):2563-81.

49. Abedon ST, Kuhl SJ, Blasdel BG, Kutter EM. Phage treatment of human infections. Bacteriophage. 2011;1(2):66-85.

50. Chen Y, Sun E, Song J, Tong Y, Wu B. Three Salmonella enterica serovar Enteritidis bacteriophages from the Siphoviridae family are promising candidates for phage therapy. Can J Microbiol. 2018;64(11):865-75.

51. Roach DR, Leung CY, Henry M, Morello E, Singh D, Di Santo JP, Weitz JS, Debarbieux L. Synergy between the host immune system and bacteriophage is essential for successful phage therapy against an acute respiratory pathogen. Cell Host Microbe. 2017;22(1):38-47 e34.

52. Loc-Carrillo C, Abedon ST. Pros and cons of phage therapy. Bacteriophage. 2011;1(2):111-4.

53. Valerio N, Oliveira C, Jesus V, Branco T, Pereira C, Moreirinha C, Almeida A. Effects of single and combined use of bacteriophages and antibiotics to inactivate Escherichia coli. Virus Res. 2017;240:8-17.

54. Ryan EM, Alkawareek MY, Donnelly RF, Gilmore BF. Synergistic phageantibiotic combinations for the control of Escherichia coli biofilms in vitro. FEMS Immunol Med Microbiol. 2012:395-8.

55. Chaudhry WN, Concepcion-Acevedo J, Park T, Andleeb S, Bull JJ, Levin BR. Synergy and order effects of antibiotics and phages in killing Pseudomonas aeruginosa biofilms. PLoS One. 2017;12(1):e0168615.

56. Oechslin F, Piccardi P, Mancini S, Gabard J, Moreillon P, Entenza JM, Resch G, Que YA. Synergistic interaction between phage therapy and antibiotics clears Pseudomonas aeruginosa infection in endocarditis and reduces virulence. J Infect Dis. 2017;215(5):703-12.

57. Parsek MR, Singh PK. Bacterial biofilms: an emerging link to disease pathogenesis. Annua Rev Microbiol. 2003;57:677-701.

58. Abdi-Ali A, Mohammadi-Mehr M, Agha AY. Bactericidal activity of various antibiotics against biofilm-producing Pseudomonas aeruginosa. Int J Antimicrob Agents. 2006;27(3):196-200.

59. Easwaran M, Dananjaya SHS, Park SC, Lee J, Shin HJ, De Zoysa M. Characterization of bacteriophage pAh-1 and its protective effects on experimental infection of Aeromonas hydrophila in Zebrafish (Danio rerio). J Fish Dis. 2017:40(6):841-6.

60. Abedon ST. Lysis from without. Bacteriophage. 2011;1(1):46-9.
61. Sutherland IW, Hughes KA, Skillman LC. Tait K the interaction of phage and biofilms. FEMS Microbiol Lett. 2004;232(1):1-6.

62. Wood SR, Kirkham J, Marsh PD, Shore RC, Nattress B, Robinson C. Architecture of intact natural human plaque biofilms studied by confocal laser scanning microscopy. J Dent Res. 2000;79(1):21-7.

63. Labrie SJ, Samson JE, Moineau S. Bacteriophage resistance mechanisms. Nat Rev Microbiol. 2010;8(5):317-27.

64. Hanlon GW, Denyer SP, Olliff CJ, Ibrahim LJ. Reduction in exopolysaccharide viscosity as an aid to bacteriophage penetration through Pseudomonas aeruginosa biofilms. Appl Environ Micro. 2001;67(6):2746-53.

65. Gutierrez D, Martinez B, Rodriguez A, Garcia P. Isolation and characterization of bacteriophages infecting Staphylococcus epidermidis. Curr Microbiol. 2010; 61(6):601-8.

66. Oliveira H, Costa AR, Konstantinides N, Ferreira A, Akturk E, Sillankorva S, Nemec A, Shneider M, Dotsch A, Azeredo J. Ability of phages to infect Acinetobacter calcoaceticus-Acinetobacter baumannii complex species through acquisition of different pectate lyase depolymerase domains. Environ Microbiol. 2017;19(12):5060-77.

67. Pang MD, Lin XQ, Hu M, Li J, Lu CP, Liu YJ. Tetrahymena: an alternative model host for evaluating virulence of Aeromonas strains. PLoS One. 2012; 7(11):e48922.

68. Hu M, Pan ZH, Lu CP, Liu YJ. Biological characterization of epidemic Aeromonas hydrophila strains. Chinese Veterinary Science. 2013;43(05):441-5.

69. Svensson V, Christiansson A. Methods for phage monitoring. FIL-IDF Bulletin. 1991;263:29-39.

70. Wang J, Zhao F, Sun H, Wang Q, Zhang C, Liu W, Zou L, Pan Q, Ren H. Isolation and characterization of the Staphylococcus aureus bacteriophage vB_SauS_SA2. AIMS Microbiol. 2019;5(3):285-307.

\section{Publisher's Note}

Springer Nature remains neutral with regard to jurisdictional claims in published maps and institutional affiliations.

Ready to submit your research? Choose BMC and benefit from:

- fast, convenient online submission

- thorough peer review by experienced researchers in your field

- rapid publication on acceptance

- support for research data, including large and complex data types

- gold Open Access which fosters wider collaboration and increased citations

- maximum visibility for your research: over $100 \mathrm{M}$ website views per year

At BMC, research is always in progress.

Learn more biomedcentral.com/submissions 